\title{
On the irrationality of rational design of an HIV vaccine in light of protein intrinsic disorder
}

\author{
Vladimir N. Uversky ${ }^{1,2}$ (1)
}

Received: 6 August 2020 / Accepted: 19 December 2020 / Published online: 19 February 2021

(c) Springer-Verlag GmbH Austria, part of Springer Nature 2021

\begin{abstract}
The lack of progress in finding an efficient vaccine for a human immunodeficiency virus (HIV) is daunting. In fact, this search has spanned nearly four decades without much success. There are several objective reasons for such a failure, which include the highly glycosylated nature of HIV-1, the presence of neotopes, and high mutation rates. This article argues that the presence of highly flexible and intrinsically disordered regions in both human anti-HIV-1 antibodies and the major HIV-1immunogen, its surface glycoprotein gp120, represent one of the major causes for the lack of success in utilization of structure-based reverse vaccinology.
\end{abstract}

Structure-based reverse vaccinology [52, 63] represents an important constituent of rational vaccine design, where an attempt is made to produce a vaccine using information from the observed crystallographic structure of neutralizing monoclonal antibodies (mAbs) bound to their complementary epitopes. Such structural vaccinology is believed to represent a way to facilitate rational design of better antigens able to act as vaccine immunogens. Computer-based reverse engineering methodology utilizes the available structures of pathogenic proteins and antigen-antibody complexes and uses docking and modeling studies to predict epitopes to reconstruct an epitope capable of $\mathrm{mAb}$ binding, where the structure of $\mathrm{mAb}$ is used as a template in a process similar to rational drug design, where the $3 \mathrm{D}$ structure of a biological target is used for designing molecules capable of the selective binding to and specific inhibition of the biological activity of a target molecule [12]. It should be noted that mAbs used in this context must have been shown to be broadly

Handling Editor: Marc H. V. Van Regenmortel.

Vladimir N. Uversky

vuversky@usf.edu

1 Department of Molecular Medicine, USF Health Byrd Alzheimer's Research Institute, Morsani College of Medicine, University of South Florida, Tampa, FL, USA

2 Institute for Biological Instrumentation of the Russian Academy of Sciences, Federal Research Center "Pushchino Scientific Center for Biological Research of the Russian Academy of Sciences”, Pushchino, Moscow Region 142290, Russia neutralizing (in vitro). Here, an assumption is made that such an antigen "rationally" designed to fit the mAb would have the desired immunogenic potential and would be able to induce polyclonal antibodies (Abs) that would possess neutralizing properties similar to those of the $\mathrm{mAb}$ used as the template for the computational reconstruction of the antigen. Alternatively, one can utilize available information on the whole genomes/proteomes of various pathogens and use computational approaches to identify the bacterial/viral surface antigens that are most likely to be vaccine candidates. The rationale of this approach is based on the assumption that virtually all of the proteins of the pathogenic microorganisms are likely to contain antigenic sites that can be predicted by computational means. Here, the entire bacterial or viral proteome is subjected to in silico analysis in order to find all of the antigens that a bacterial or viral pathogen is able to express [52,63]. Again, structural vaccinology is utilized here for prediction and characterization of structural epitopes of immunogenic antigens. At the next stage of both approaches, the ability of individual antigens to elicit immunity in animal models is tested [13,65].

There is no doubt that reverse vaccinology has open new horizons, and this is supported by multiple research studies and dedicated reviews that emphasize the strengths and successes of this approach for rapid targeted identification of novel vaccine antigens as well as for improving the immunogenicity and safety of vaccine antigens $[12,13,52,63$, 65]. Examples include development of strongly immunogenic vaccine candidates based on the respiratory syncytial virus (RSV) glycoprotein and the spike protein of Middle 
East respiratory syndrome coronavirus (MERS-CoV) [39, 59]. Broadly neutralizing antibodies (bNAbs) against the influenza virus hemagglutinin stalk and the dengue virus envelope protein were discovered using structure-guided design and high-throughput in vitro assays $[38,66,76]$. The culmination of the success of this strategy is the successful development of designer antigens, where structural information pertaining to existing bNAbs-antigen complexes was utilized to design linear and discontinuous HIV epitopes that were grafted onto computationally designed scaffolds $[5,6]$.

Despite all these and many similar success stories of the application of rational vaccine design, and despite the fact that several broadly neutralizing anti-HIV-1 Abs have been found (e.g., IgG1 b12 targeting the HIV-1 envelope glycoprotein gp120 of the viral spike [95] and IgG 2G12, which recognizes a carbohydrate epitope on gp120 [92]), not a single promising HIV vaccine has been found after nearly 40 years of research utilizing various approaches, including structure-based reverse vaccinology [22, 27, 28, 91]. Among the accepted explanations for these failures are the high glycosylation level of the HIV surface (e.g., HIV is the most glycosylated virus known [87], with glycans composing up to half of the only surface HIV-1 protein, the Env protein [49]) and the presence of rather recently described neotopes (or neo-antigenic sites) in HIV-1 gp120 (neotopes have been described in many viruses since 1966 [85], but only recently in HIV [34]). Here, neotopes are novel transient epitopes that are not present in the viral protein monomers but arise from the quaternary structure of a multimeric assembly of identical subunits of viral proteins, either from the juxtaposition of residues in neighboring subunits that are recognized by Abs as a single epitope or from conformational changes induced in the protein by intersubunit interactions [56]. Curiously, although the term neotope was coined by Prof. Marc H. V. van Regenmortel in 1966 [85], for a long time, this phenomenon was mostly studied by plant virologists studying the serological properties of plant viruses. In the field of animal/human viruses, the importance of neotopes became commonly recognized much later [86]. As a result, until quite recently, vaccine designers looked only at the monomeric forms of pathogen-derived proteins, despite the recognition that the neotope can be formed via several mechanisms. For example, complex-specific, neo-antigenic sites that are not detectable on monomeric proteins but are found in complexes of target proteins with receptors are rather common [83, 84]. The neo-epitopes can also appear due to the dissociation of the native oligomeric forms of proteins into free subunits (e.g., C-reactive protein, CRP [69]). Another common mechanism of neotope formation includes specific cleavage of target proteins by proteases [11]. Also, neotopes can originate due to specific posttranslational modifications of target proteins $[1,4]$. Finally, neotopes can be generated as a result of structural perturbations of target proteins induced by free radicals and oxidative damage [30, 73], as is the case in autoimmune rheumatoid disease [30, 73]. It is also implied that HIV infection typically promotes an immune response against highly variable immunodominant epitopes (e.g., the V1, V2, and V3 loops of the envelope glycoprotein gp160) that does not provide protection against diverse HIV strains [65]. Like other retroviruses, HIV utilizes an error-prone polymerase for replication, and the resulting high rate of mutation accounts for many of the difficulties in the search for the HIV vaccine [27, 28, 91]. It seems that this situation is similar to that of influenza virus, which serves as a well-known illustration of the correlation between high mutation rates and difficulties in finding effective vaccines [27]. However, the influenza vaccine analogy is not strictly applicable to HIV, since the efficacy of the correctly anticipated influenza vaccine mix can be as high as 69-83\% [58], whereas the maximal efficacy of an HIV vaccine has so far reached only about $30 \%$ [22]. This is an interesting observation taking into account that, since the late 1980s, more than 100 candidate prophylactic vaccines have been tested in phase 1 clinical trials but only a few of those have advanced to the stage of phase $2 b$ or phase 3 efficacy studies [22], of which only one candidate vaccine, ALVAC, has shown modest efficacy of $31.2 \%$ [4, 22, 75]. Recently, a modified version of this partially effective HIV vaccine failed to show efficacy in preventing HIV, and the corresponding \$100 million clinical trial HVTN 702 in South Africa evaluating it has been stopped early (https://www. niaid.nih.gov/news-events/experimental-hiv-vaccine-regim en-ineffective-preventing-hiv). Importantly, not all retroviruses are without vaccines, as effective vaccines for equine infectious anemia virus (EIAV) have been developed [19, 50, $51,55,82,89,90]$, whereas there are still no vaccines for the non-retroviral RNA virus hepatitis $\mathrm{C}$ virus (HCV) or the DNA virus herpes simplex virus (HSV) [7, 10].

The major immunogens of HIV-1 are trimeric spikes formed by Env heterodimers of gp41 and gp120 originating during Env maturation as a result of cleavage of the full-length gp 160 protein by a protease. The surface of the virus is decorated by 14 such spikes [9, 72]. Although many bNAbs to the Env protein of HIV-1 interact directly with glycans (e.g., the aforementioned IgG $2 \mathrm{G} 12$, which recognizes a carbohydrate epitope on gp120 [92]), some of the bNAbs do interact with the proteinaceous part of gp120 (e.g., IgG1 B12 [45, 95]). Let us consider some structural aspects of 
such antigen-Ab interactions, which constitute the foundation of structure-based reverse vaccinology and rational structural vaccinology in general.

We will start with a brief description of the Ab structural organization. Although there are five different classes of Abs, which are commonly known as immunoglobulins, $\operatorname{IgM}, \operatorname{IgD}, \operatorname{IgG}, \operatorname{Ig} \mathrm{A}$, and $\operatorname{IgE}$, they all have a comparable structural organization of functional units, and we will focus here on IgG. A well-recognized image of a typical $\mathrm{Ab}$ is a Y-shaped molecule consisting of three equal-sized parts that are connected by flexible linkers (Fig. 1A) and have different functions, with the arms (or variable [V] regions, since they vary among different antibody molecules, or antigen-binding fragment, $\mathrm{F}_{\mathrm{ab}}$ ) being involved in specific antigen binding, and with the stem part (or constant fragment, $\mathrm{F}_{\mathrm{c}}$ ) being less variable and responsible for interactions with various effectors. Importantly, since in the Abs, the "arms" are connected to the "stem" via flexible linkers, the resulting Y-shaped molecules are highly flexible (with the hinge regions connecting the $F_{a b}$ fragments to the $F_{c}$ domains being especially mobile), and therefore, known Ab crystal structures can only be considered "snapshots" of the broad range of conformations available to these proteins in solution [71]. This high conformational flexibility of the hinges connecting $\mathrm{F}_{\mathrm{ab}}$ fragments with the $F_{c}$ fragment represents a major reason for the sparsity of resolved crystal structures of full-length immunoglobulins.

Zooming in to the "active sites" of Abs reveals that they have two identical binding clefts located within the N-terminal regions of their $\mathrm{H}$ and $\mathrm{L}$ chains. Each of these binding clefts is made up of 50-70 hypervariable residues and includes several overlapping paratopes; i.e., binding subsites of 10-20 residues, which are structurally and chemically complementary to the epitopes; i.e., certain patches of residues present at the surface of the target protein [29]. These paratopes are built from short stretches of residues located on six complementarity determining regions (CDRs, $\mathrm{L} 1, \mathrm{~L} 2, \mathrm{~L} 3$ on the light chain and $\mathrm{H} 1, \mathrm{H} 2$, and $\mathrm{H} 3$ on the heavy chain) that form discontinuous binding sites. Therefore, these six CDRs of each $\mathrm{Ab}$ arm are able to come into contact with the antigen. One should keep in mind, though, that although as many as all six CDRs can contribute amino acid residues to the contact surface with the antigen, often, fewer than six CDRs actually do so, and as few as four CDRs might contribute to contact with the antigen. Furthermore, the effectiveness of camelid $\mathrm{V}_{\mathrm{H}^{-}}$-only antibodies suggests that perhaps fewer than four CDRs could be involved in contacting antigen in some complexes. Typically, the antigen-binding sites of anti-protein Abs are relatively flat. However, H3 loops (which are located in the center of the binding site) in human Abs are often extended [8, 41, 70, 71], allowing them better access to the canyons and clefts on the antigen surface $[71,77]$. Many of these H3 loops in human Abs are characterized by unique structural features [64]. This is illustrated by an important study of known 3D structures of human Abs (1,779 structures with 4,989 chains), which revealed that the H3 loops contain on average 10 times more unique conformations than the other loops, with more than a thousand four-residue-long fragments of $\mathrm{H} 3$ adopting conformations not seen in any other structure [64]. This enormous polymorphism of the available structures of the H3 loop is likely a reflection of its highly flexible or even disordered nature in solution, where this loop exists as a highly dynamic conformational ensemble, and each crystal structure represents a snapshot showing one member of this ensemble. In line with these considerations are the results of an analysis of the predisposition for intrinsic disorder in both the $\mathrm{H}$ and $\mathrm{L}$ chains of a typical IgG (human antibody IgG1 B12) (Fig. 1B and $\mathrm{C}$, respectively). This analysis revealed that both chains contain several intrinsically flexible or disordered regions (i.e., regions with a predicted disorder score (PDS) $\geq 0.5$ or $0.15 \leq$ PDS $<0.5$, respectively), with the CDRs being predicted to be either flexible or disordered. This strongly suggests that the information about conformational plasticity is encoded in the amino acid sequences of these important regions. Figure $1 \mathrm{~B}$ and $\mathrm{C}$ show another interesting feature of the $\mathrm{H}$ and $\mathrm{L}$ chains, namely the presence of redox-sensitive regions (i.e., cysteine-containing regions capable of undergoing disorder-to-order or order-to-disorder transitions in response to changes in the redox state of the environment [54]).

Figure 2 shows that, in different anti-HIV Abs of human or bovine origin, the $\mathrm{H} 3$ loop length can vary over a very wide range, from four residues in the non-neutralizing HIV antibody 13H11 (PDB ID: 3MO1) to 16 residues in the broadly reactive and potent HIV-1-neutralizing human antibody PG9 (PDB ID: 3U1S; [53]), and to 60 residues in the potent HIV-1 bNAb NC-Cow1 (PDB ID: 6OO0; [81]). Importantly, the overall close resemblance of these structures is determined by their high sequence similarity (sequence identity of these chains ranges from $48.33 \%$ to $88.61 \%$ ). Furthermore, a multiple structural alignment revealed that these 10 structures, ranging in length from 215 to 273 residues, can be aligned over the region of 98 residues (corresponding to the $\mathrm{N}$-terminal domain of the $\mathrm{V}_{\mathrm{H}}$; i.e., the $\mathrm{V}$ domain of the $\mathrm{H}$ chain) with a root-mean-square deviation (RMSD) of $0.83 \AA$, and the region of the successful structural alignment (with an RMSD below $1 \AA$ ) can increase 

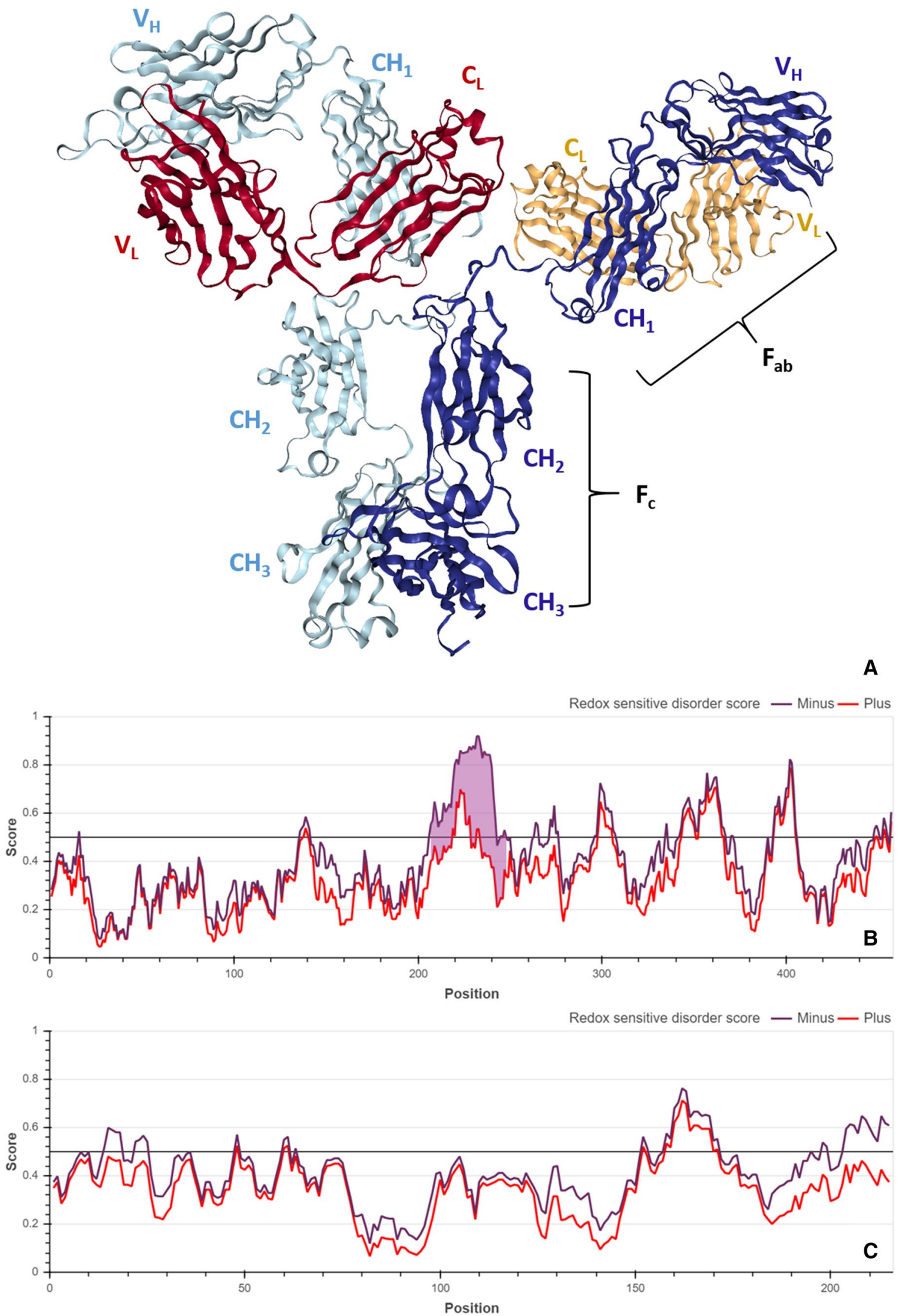
४Fig. 1 Structure and disorder in human IgG. A. Crystal structure of the intact human IgG B12 with broad and potent activity against primary HIV-1 isolates (PDB ID: 1HZH) [71]. This Y-shaped structure originates from the specific packing of four protein chains, two identical heavy $(\mathrm{H})$ chains (blue and cyan structures) and two identical light (L) chains (red and orange structures), each composed of variable and constant regions located at the $\mathrm{N}$ - and $\mathrm{C}$-terminal parts of the chains, respectively. In IgG, each L chain is made up of two independent domains with a typical immunoglobulin fold, whereas each $\mathrm{H}$ chain has four such domains. The antigen-binding $\mathrm{V}$ region of the $\mathrm{Ab}$ (the $\mathrm{F}_{\mathrm{ab}}$ fragment) is made of the variable $\mathrm{V}$ domains of the $\mathrm{H}$ and $\mathrm{L}$ chains $\left(\mathrm{V}_{\mathrm{H}}\right.$ and $\mathrm{V}_{\mathrm{L}}$, respectively), whereas the $\mathrm{Ab}$ constant region (the $\mathrm{F}_{\mathrm{c}}$ fragment) is made of the constant $\mathrm{C}$ domains of the $\mathrm{H}$ and light $\mathrm{L}\left(\mathrm{C}_{\mathrm{H}}\right.$ and $\mathrm{C}_{\mathrm{L}}$, respectively). The overall structure is maintained not only by specific chain-chain interactions but also by a network of disulfide bonds that link the two $\mathrm{H}$ chains to each other in the $\mathrm{F}_{\mathrm{c}}$ region and also link each $\mathrm{H}$ chain to an $\mathrm{L}$ chain in each $\mathrm{F}_{\mathrm{ab}}$ region. Utilization of the two identical $\mathrm{H}$ chains and the two identical L chains to form a Y-shaped structure results in the formation of two identical antigen-binding sites in any given immunoglobulin molecule, which are able to simultaneously interact with two identical structures. B. Intrinsic disorder predisposition and the presence of redox-sensitive regions (i.e., cysteine-containing regions capable of undergoing disorder-to-order or order-to-disorder transitions in response to changes in the redox state of the environment) in a heavy chain of the human antibody IgG1 B12. A redox-sensitive region is shown with dark red shading. C. Intrinsic disorder predisposition and the presence of the redox-sensitive regions in a light chain of the human antibody IgG1 B12. Profiles shown in plots $\mathbf{B}$ and $\mathbf{C}$ were generated using the IUPred2A platform [54]

to more than 220 residues if the structures are aligned in a pairwise manner. In these pairwise alignment experiments, the only region that fails to align is the CDR H3 loop, and these loops are the most variable regions in the image showing a multiple structural alignment (see Fig. 2). Figure 2 also shows that the exceptionally long disulfide-rich CDR H3 of NC-Cow1 forms a mini-domain (knob) on an extended stalk [81]. In a crystal structure of the $\mathrm{F}_{\mathrm{ab}}$ NC-Cow1 in complex with the HIV Env trimer BG505 SOSIP, this knob on the stalk "navigates through the dense glycan shield on Env to target a small footprint on the gp120 CD4 receptor binding site with no contact of the other CDRs to the rest of the Env trimer" [81]. Curiously, it has been pointed out that the length of a CDR H3 loop may play a role in the neutralization potential of a given $\mathrm{Ab}$, with the long CDR H3 loops being among the most important structural features found in broadly neutralizing antibodies (bNAbs) $[62,97]$. This is likely because long CDR H3 loops can penetrate the dense glycan shield of HIV Env to access the protein surface of this viral glycoprotein $[35,97]$. From this perspective, the "knob on an extended stalk" structure of an extra-long CDR $\mathrm{H} 3$ loop found in $~ 10 \%$ of bovine immunoglobulins, including the potent vaccine-induced anti-HIV-1 bNAb NC-Cow1
[81], might serve as a perfect "penetrator" that can navigate through the glycan shield on Env. In fact, in bovine immunoglobulins, the length of such extra-long CDR H3 loops can reach 70 residues $[15,68,88]$, which is almost twice as long as the longest CDR H3 loop (38 residues) found in human bNAbs [97]. As a result, these extra-long CDR H3 loops can protrude up to $40 \AA$ above the tips of the other CDR loops [81]. It is likely that such a structural organization of the CDR H3 loop defines the functionality of the broadly neutralizing bNAb NC-Cow1, which exhibits $72 \%$ neutralization breadth against a 117-virus panel, with a halfmaximal inhibitory concentration $\left(\mathrm{IC}_{50}\right)$ of $0.028 \mu \mathrm{g} / \mathrm{ml}$ [79].

Figure $3 \mathrm{~A}$ shows that despite the high content of cysteine residues, this CDR $\mathrm{H} 3$ of NC-Cow 1 is predicted to be rather flexible, whereas Figure 3B suggests that this region is characterized by a strong redox-sensing potential and is expected to undergo an order-to-disorder transition when disulfides are reduced. Figure $3 \mathrm{C}$ and D illustrate that the CDR H3 loop of different Abs shown in Figure 2 are all predicted to be flexible or disordered, with the degree of disorderedness increasing with the length of the H3 loop. One should also keep in mind that with a very high probability, the observed structures of these long $\mathrm{F}_{\mathrm{ab}}$ appendices are stabilized (or even induced) by interaction of the Ab with antigens or by the crystal lattice. Here, "a protein crystal lattice consists of surface contact regions, where the interactions of specific groups play a key role in stabilizing the regular arrangement of the protein molecules" within a crystal [94]. Obviously, some of these interactions between specific groups in the surface contact regions of proteins within the crystal lattice can reduce conformational flexibility and induce structuration. These observations strongly suggest that conformational flexibility and intrinsic disorder are crucial for the functionality of anti-HIV-1 Abs (or at least for the binding efficiency of their $\mathrm{H} 3$ loops).

It is time now to consider intrinsic disorder-related features of the major immunogen of HIV-1, its gp120 protein, which is a constituent of the trimeric spikes of this virus and which attaches the virus to the host lymphoid cell by binding to the primary receptor CD4. Figure 4A shows the disorder profile of the full-length gp120 of HIV-1 group M subtype B (isolate YU-2), which is a 467-residue-long surface protein containing variable regions V1 through V5 (residues 98-122, 123-160, 260-293, 348-373, and 416-426), which are the most genetically diverse regions of the entire HIV-1 genome, as well as a CD4-binding loop (residues 327-337). All of these functional regions of gp120 are located within or in close proximity to disordered regions. It is of interest to 


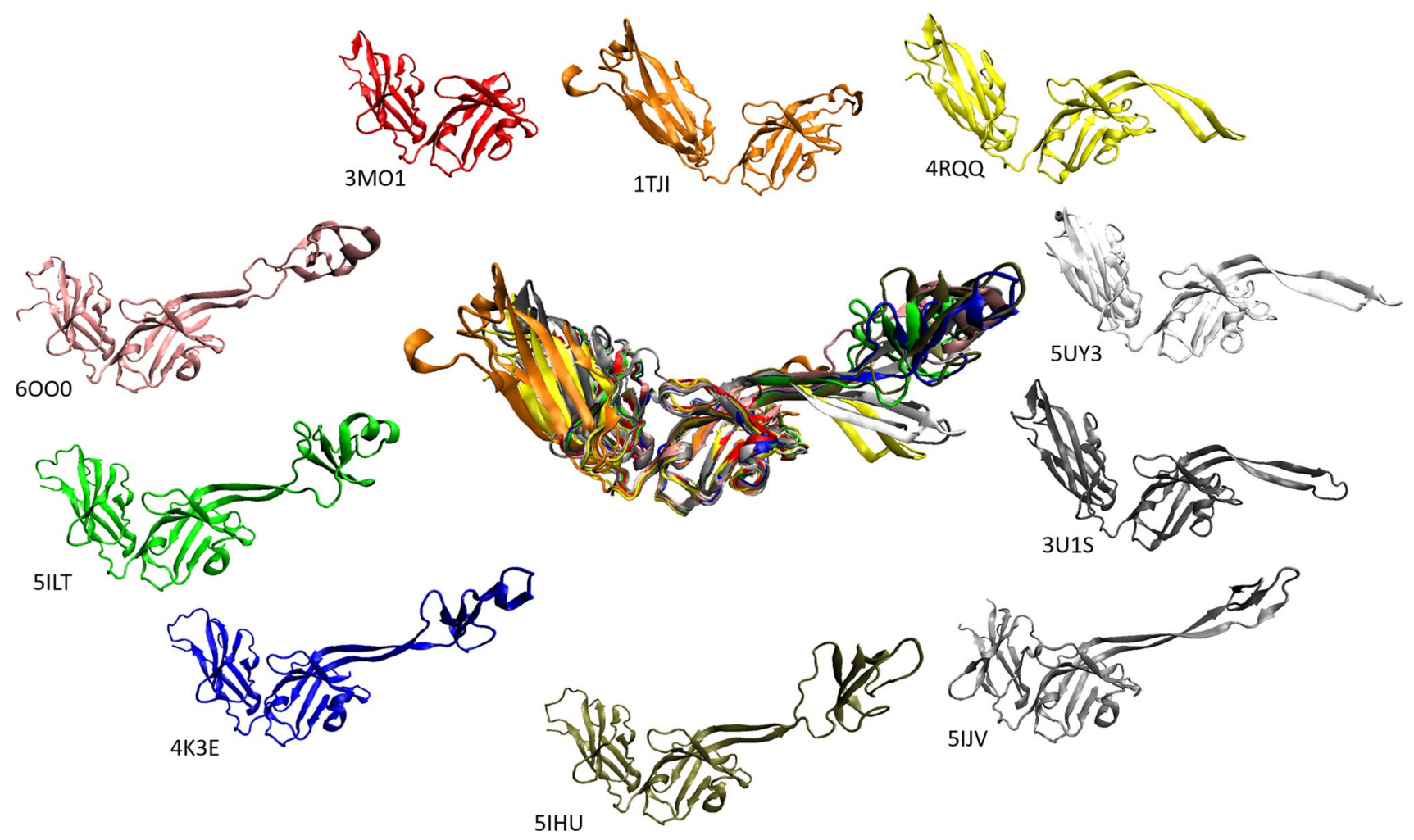

Fig. 2 Structural diversity of the $\mathrm{H}$ chains of anti-HIV Abs of human or bovine origin, illustrating that the length of the H3 loop can vary over a very wide range. The illustration shows the $\mathrm{H}$ chain of the nonneutralizing HIV antibody $13 \mathrm{H} 11 \mathrm{~F}_{\mathrm{ab}}$ fragment (PDB ID: 3MO1:B); the $\mathrm{H}$ chain of the broadly neutralizing anti-HIV-1 antibody $2 \mathrm{~F} 5$ in complex with a gp41 17mer epitope (PDB ID: 1TJI:H) [57]; the $\mathrm{H}$ chain of human Fab PGDM1400, a broadly reactive and potent HIV-1 neutralizing antibody (PDB ID: 4RQQ:B) [78]; the $\mathrm{H}$ chain of human $F_{a b}$ PGT144, a broadly reactive and potent HIV-1 neutralizing antibody (PDB ID: 5UY3:H) [47]; the H chain of human Fab PGT145, a broadly reactive and potent HIV-1 neutralizing antibody (PDB ID: 3U1S:H) [53]; the ultralong $\mathrm{H}$ chain of bovine $\mathrm{F}_{\mathrm{ab}}$ E03 (PDB ID: 5IJV:H) [80]; the $\mathrm{H}$ chain of bovine $\mathrm{F}_{\mathrm{ab}}$ B11 (PDB ID: 5IHU:H)

note that, in the majority of the crystallization experiments, various shorter forms of the protein were used instead of the full-length gp120. The disorder profiles for two illustrative examples of these so-called gp120 core forms are shown in Figure 4B (the extended gp120 core, 376 residues) and Figure $4 \mathrm{C}$ (the gp120 core from the HXBc2 laboratoryadapted isolate, 306 residues). Comparison of the disorder profiles shown in Figure 4 clearly indicates that some disordered/flexible regions had been removed from the gp120 core constructs used in the crystallization experiments. For example, in the extended gp120 core, these removed regions are residues 90-165, and 265-288 of the full-length gp120, which clearly correspond to its variable regions V1, V2,
[80]; the $\mathrm{H}$ chain of bovine antibody BLV5B8 with ultralong CDR H3 (PDB ID: 4K3E:H) [88]; the $\mathrm{H}$ chain of bovine $\mathrm{F}_{\mathrm{ab}}$ A01 (PDB ID: 5ILT:H) [80]; and the $\mathrm{H}$ chain of a vaccine-induced cow antibody with broad HIV neutralization capability (PDB ID: 6OO0:H) [81]. Structures are shown as ribbon diagrams. In the middle of the figure is a multiple structure alignment of the indicated structures $(5 \mathrm{IHU}$, 273 residues; 5ILT, 271 residues; 6OO0, 268 residues; 4K3E, 262 residues; 5IJV, 246 residues; 4RQQ, 239 residues; 3U1S, 238 residues; 1TJI, 236 residues; 5UY3, 229 residues; 3MO1, 215 residues) that was made using the MultiProt algorithm (http://bioinfo3d.cs.tau. ac.il/MultiProt/) [74]. The alignment of 98 residues achieved an RMSD of $0.83 \AA$

and a significant part of $\mathrm{V} 3$, whereas in the gp 120 core from the $\mathrm{HXBc} 2$ laboratory-adapted isolate, the removed regions are residues 1-50, 96-159, 264-293, and 448-467, which, in addition to the $\mathrm{N}$ - and $\mathrm{C}$-tails, include the variable regions $\mathrm{V} 1, \mathrm{~V} 2$, and V3. To illustrate the structural variability of the gp120 cores utilized in crystallographic experiments, Figure 5 shows the results of multiple structural alignment for 10 such chains ranging in length from 288 to 343 residues and shows that these structures can be accurately aligned over the region of 234 residues with an RMSD of $0.66 \AA$. This analysis shows that although 70 to $80 \%$ of these structures are very similar, the remaining parts of each chain show unique structural features. 
Similar to other rational structure-based drug discovery approaches, rational structural vaccinology uses the known $3 \mathrm{D}$ structure of an $\mathrm{Ab}$ to find epitopes that would form specific epitope-paratope complexes. However, the data considered in this article indicate that both partners that are used in such structure-based rational design of antiHIV vaccines (gp120 and Abs) are characterized by high conformational plasticity and have regions with considerable intrinsic disorder. This raises serious doubts about the overall applicability of such computational methods in this case. In fact, structure-based rational design is based on considering complexes (protein-ligand, protein-protein, protein-nucleic acid or antigen-antibody, as in this particular case) in terms of rigid, motionless structures with steric complementarity to each other. This approximation goes back to the famous lock-and-key model of enzyme catalysis proposed by Hermann Emil Fischer [23, 48] and the "side-chain theory" suggested by Paul Ehrlich for antigen-antibody complexes more than a century ago [18, $21,33,46]$. However, protein-protein binding involves a process of induced complementarity and fit resulting from the mutual adjustments of the two partners that involve important side-chain movements and changes in the backbone conformation, as in the flexible keys and adjustable locks model that was proposed by Edmundson et al. in 1987 [20] based on the induced-fit model suggested earlier by Daniel Edward Koshland for enzyme catalysis [37]. In this induced-fit model, the fit between an active site and a substrate is brought about by substrate binding, since the spatial positioning and the 3D relationship of the amino acids at the active site of an enzyme can be changed by binding of the substrate, and such substrate-induced structural changes bring the catalytic groups into the proper orientation for the reaction, which does not occur with a non-substrate [37]. This also indicates that a binding site is a relational entity, undergoing "fine tuning" in response to interaction with a partner, and it is not solely defined by intrinsic structural features that are identifiable independently of the relationship with a particular partner. Obviously, these considerations apply to all partners involved in complex formation, since their binding sites are engaged in mutual tuning. One should also keep in mind that the scale of such mutual tuning can range from rather minimal structural adjustments to global binding-induced folding.

Finally, there is another intrinsic-disorder-related angle in the mystery of the HIV-1 vaccine failure. It has been pointed out that the HIV-1 matrix protein (p17) is expected to be highly disordered [25]. In fact, based on computational analysis, it was concluded that, depending on a strain, the percentage of intrinsic disorder (PID, which is the percentage of residues with PDS $\geq 0.5$ ) in p17 can be as high as $70 \%$, a level encountered very rarely in the outer shell of other viruses $[25,26]$. This is further supported by an analysis of the shell disorder status of over 300 viruses in the publicly available database [24,28], which indicates that, in addition to HIV-1, the outer-shell proteins of herpes simplex virus (HSV) and hepatitis $\mathrm{C}$ virus (HCV) are highly disordered as well [27]. Curiously, successful vaccines have not been established for these three viruses (HIV-1, HSV, and HCV) with highly disordered outer shells, suggesting that the motions arising from the disordered outer shell might lead to the inability of antibodies to bind tightly to the polysaccharides on the viral surface proteins or to the viral surface proteins themselves, rendering the immune response inadequate [27]. Therefore, the failure of vaccines based on the HIV glycoprotein gp120 and other vaccines can be traced back to a lack of understanding of the important role of shell disorder in immune evasion by such viral shapeshifters [27].

Recently, the results of a systematic analysis of the intrinsic disorder in shells of various viruses in relation to vaccine development were reported [27]. It was shown that successful vaccines have been developed for influenza, smallpox, rabies, polio, and yellow fever, all of which are caused by viruses characterized by a relatively low level of intrinsic disorder in the outer shell. On the other hand, there are no efficient vaccines against EIAV, HIV-1, HIV-2, HSV-1, HSV-2, or HCV, all of which show higher intrinsic disorder in their shells. In line with these considerations is the recent success with the development of the anti-SARS-CoV-2 vaccines. In fact, although the maximal proportion of intrinsically disordered residues in the outer shells of HIV-1, HCV, and HSV reaches 70, 53, and 63\%, respectively, in SARS-CoV and SARS-CoV-2, the corresponding values are much lower: 8 and $6 \%$, respectively [27].

One should keep in mind that in accounting for the lack of success to date in the quest for an HIV-1 vaccine, it is impossible to determine, even roughly, the relative contributions of the high mutation rate of HIV or the specific structural features of gp120, such as its heavily glycosylated state, and the appearance of quaternary-structure-dependent neotopes versus the contribution of conformational flexibility or the presence of intrinsically disordered regions. This is because all of these seemingly structure-related features are intertwined with intrinsic disorder and structural flexibility. In fact, in viral proteins (and proteins in general), mutations most commonly occur in flexible or disordered regions. Quaternary 

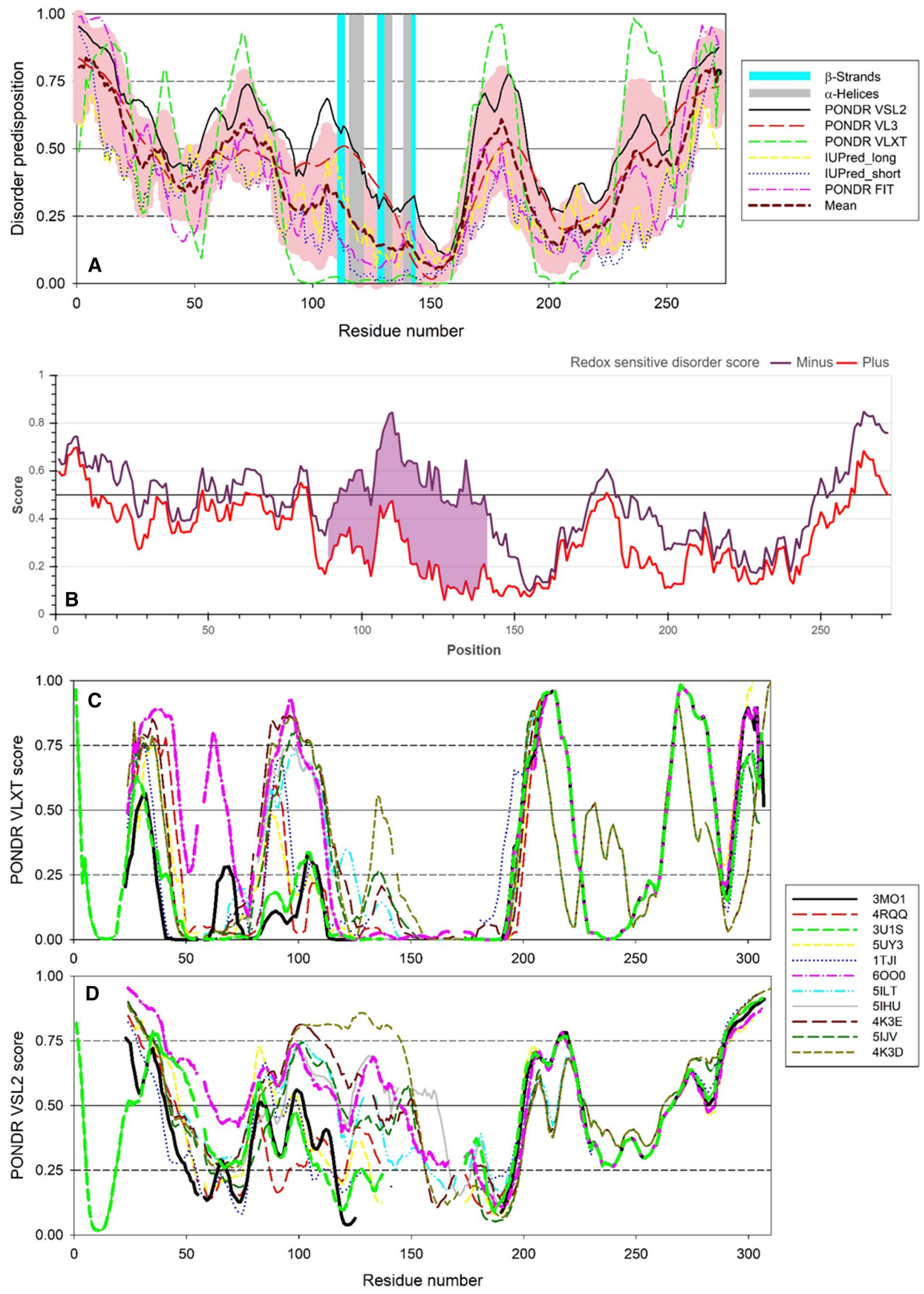
4Fig. 3 Intrinsic disorder predispositions of the $\mathrm{H}$ chains of human and bovine $\mathrm{F}_{\mathrm{ab}} \mathrm{s}$. A. Multifactorial analysis of the intrinsic disorder predisposition of the $\mathrm{H}$ chain of the potent HIV-1 bNAb NC-Cow1. The disorder profile was generated using a DiSpi web crawler designed to aggregate the results from a number of well-known disorder predictors: PONDR ${ }^{\circledR}$ VLXT [67], PONDR ${ }^{\circledR}$ VL3 [61], PONDR ${ }^{\circledR}$ VLS2 [60], PONDR ${ }^{\circledR}$ FIT [93], IUPred2 (Short), and IUPred2 (Long) [16, 17]. This tool enables the rapid generation of disorder profile plots for individual polypeptides as well as arrays of polypeptides. Positions of various secondary structure elements in the mini-domain (knob) located at the tip of the long CDR H3 are shown. Here, $\beta$-strands are found at residues 111-113, 128-130, and 142-143, whereas $\alpha$-helices are located at residues 116-121, 131-133, and 139-141. In reference 82 , it was pointed out that "the knob domain begins with a conserved CPED motif (CPDG in the germline) containing a type I $\beta$-turn around PEDY, followed by three very short, antiparallel $\beta$-strands (D6-D8, D23-D25, and D37-D38) with two intervening loops of 14 and 11 residues. Loop 1 forms a single turn of helix, while loop 2 has two small helical turns. The knob has three disulfide bonds with 1-4, 2-5, and 3-6 connectivity (D2-D23, D12-D32, and D21-D37)." B. Evaluation of the redox sensitivity of the $\mathrm{H}$ chain of the potent HIV-1 bNAb NC-Cow1 (i.e., the presence of the cysteine-containing regions capable of undergoing disorder-to-order or order-to-disorder transitions in response to changes in the redox state of the environment) of the $\mathrm{H}$ chain of the potent HIV-1 bNAb NC-Cow1. A redoxsensitive region is shown with dark red shading. C. Aligned intrinsic disorder profiles of the $\mathrm{H}$ chains of various human and bovine $\mathrm{F}_{\mathrm{ab}} \mathrm{s}$ generated using PONDR ${ }^{\circledR}$ VLXT [67]. D. Aligned intrinsic disorder profiles of the $\mathrm{H}$ chains of various human and bovine $\mathrm{F}_{\mathrm{ab}}$ s generated using PONDR ${ }^{\circledR}$ VSL2 [60]. Gaps in these plots correspond to gaps in the multiple sequence alignment of the corresponding chains

structure formation is frequently associated with folding upon binding events; i.e., flexible or disordered regions of protomers undergo a transition to a more ordered state as a result of oligomerization or complex formation. Therefore, at least some neotopes originate due to this binding-induced folding. Finally, the sites of many posttranslational modifications (glycosylation included) are located within disordered, or at least flexible, regions.

All of these considerations suggest that attempts to use rational structure-based design for the development of HIV vaccines are rather spurious. In fact, since neither the $\mathrm{Ab}$ nor gp120 (nor, as a matter of fact, any other antigen) has a static rigid structure, the use of such rational structure-based design in these cases resembles searching in vain under the streetlight for keys lost in a dark alley. Curiously, intrinsic disorder is considered the major reason for the existence of the dark proteome comprising proteins that are not amenable to experimental structure determination by existing means and that are inaccessible to homology modeling [40]. These considerations are very important, cannot be ignored, and clearly should be taken into account while thinking about novel approaches to HIV vaccine design. It is time to move away from playing with the motionless toys. Reality is more complex than the static "lock-and-key". In fact, it is even more complex than the "flexible keys and adjustable locks" model. 

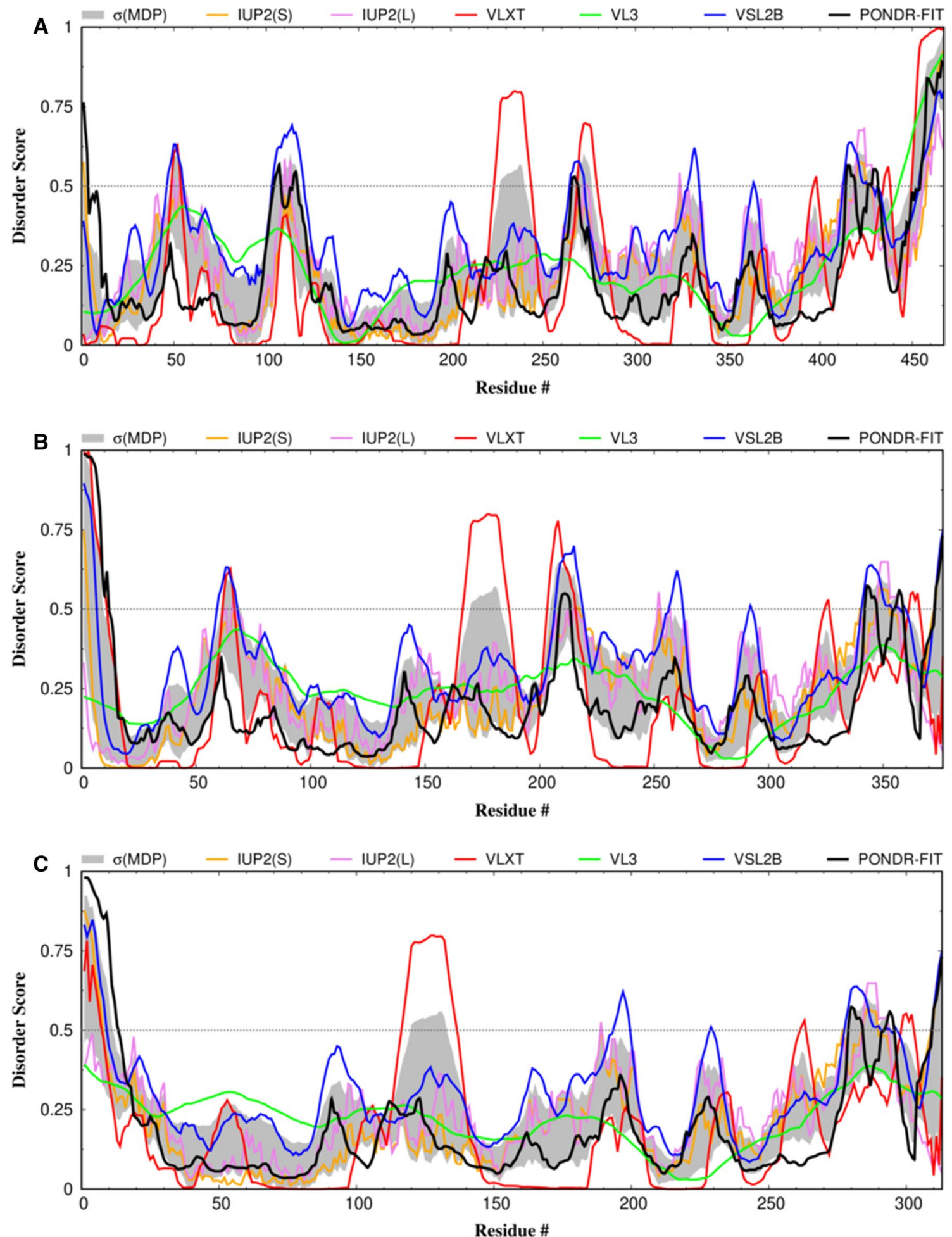

Fig. 4 Characterization of intrinsic disorder predisposition of various gp120 forms used in the crystallization experiments. A. Intrinsic disorder profile of the full-length (467 residues) gp120 of HIV-1 group M subtype B (isolate YU-2). B. Intrinsic disorder profile of the extended gp120 core (376 residues). C. Intrinsic disorder profile of the gp120 core of a laboratory-adapted $\mathrm{HXBc} 2$ isolate (306 residues).
Disorder profiles were generated using a DiSpi web crawler designed to aggregate the results from a number of well-known disorder predictors: PONDR ${ }^{\circledR}$ VLXT [67], PONDR ${ }^{\circledR}$ VL3 [61], PONDR ${ }^{\circledR}$ VLS2 [60], PONDR ${ }^{\circledR}$ FIT [93], IUPred2 (Short), and IUPred2 (Long) [16, 17] 


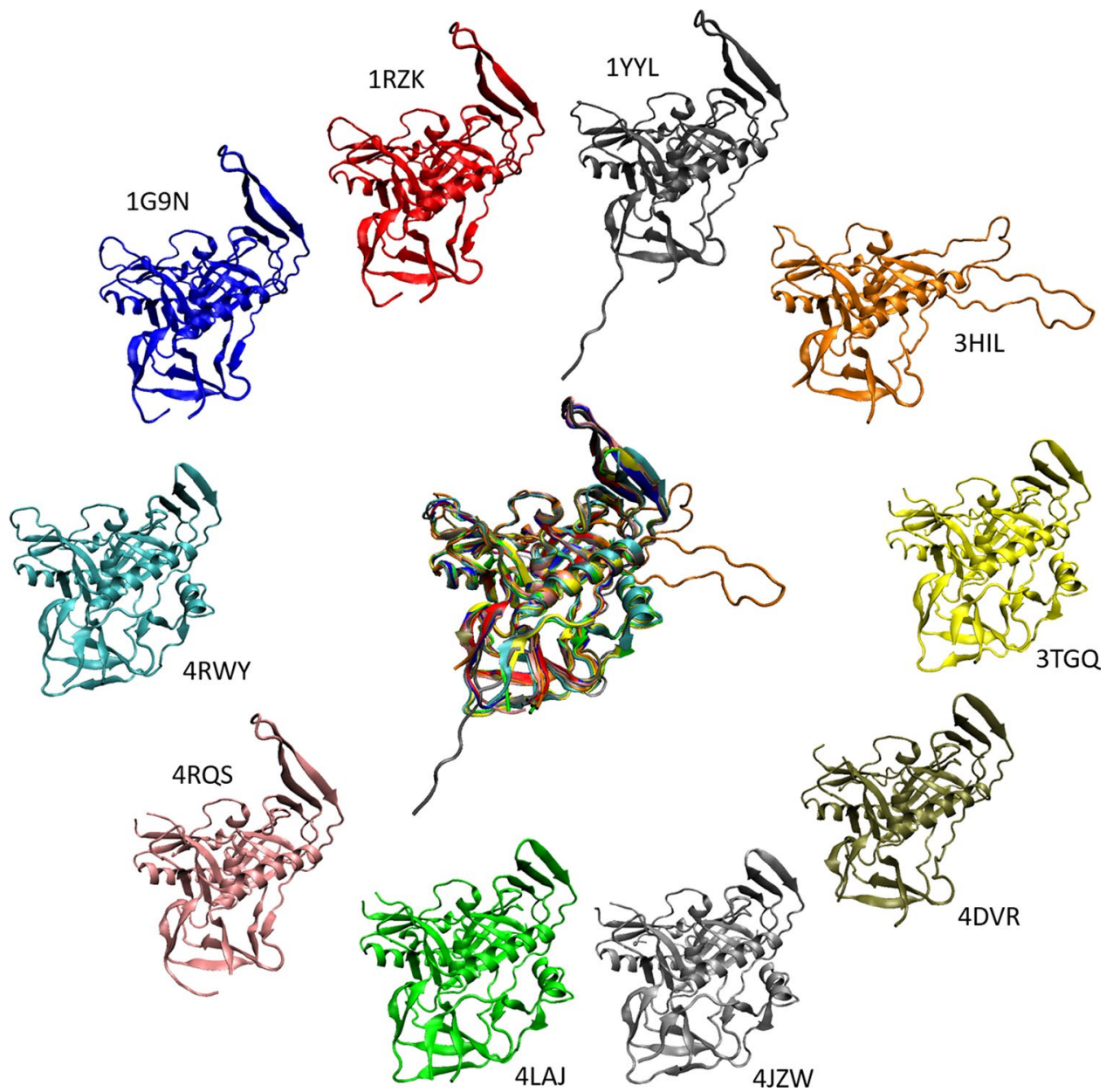

Fig. 5 Structure of gp120 in different bound forms. Comparison of the gp120 structures complexed with the CD4-binding-site antibody F105 (PDB ID: 3HI1:G) [14]; complexed with CD4 and the induced neutralizing antibody 17B (PDB ID: 1G9N:G) [44]; complexed with CD4 and the induced neutralizing antibody (PDB ID: 1RZK:G) [31]; complexed with CD4M33, a scorpion-toxin mimic of CD4 and antiHIV-1 antibody 17B (PDB ID: 1YYL:G) [32]; unliganded HIV-1 gp120 core (PDB ID: 3TGQ:A) [42]; in complex with Fab 48d and NBD-557 (PDB ID: 4DVR:G) [43]; complexed with CD4-mimetic miniprotein M48U1 (PDB ID: 4JZW:G) [3]; in complex with the CD4-mimetic miniprotein M48U1 and the llama single-domain, broadly neutralizing, co-receptor binding site antibody JM4 (PDB

Funding The author did not receive support from any organization for the submitted work.

Availability of data and material All data generated or analyzed during this study are included in this published article.

\section{Compliance with ethical standards}

Conflict of interest The author certifies that he has no affiliations with or involvement in any organization or entity with any financial interest or non-financial interest in the subject matter or materials discussed in this manuscript.
ID: 4LAJ:A) [2]; bound to CD4 and 17B $F_{a b}$ (PDB ID: 4RQS:G) [36]; and in a complex with VH1-46 germline-derived CD4-binding site-directed antibody 8ANC131 (PDB ID: 4RWY:A) [96]. Structures are shown as ribbon diagrams. In the middle of the figure is a multiple structure alignment of the indicated structures (4LAJ, 343 residues; 4JZW, 339 residues; 4RWY, 337 residues; 3TGQ, 336 residues; 1RZK, 306 residues; 1G9N, 306 residues; 1YYL, 301 residues; 4RQS, 295 residues; 3HI1, 289 residues; 4DVR, 288 residues) that was made using the MultiProt algorithm (http://bioinfo3d.cs.tau.ac.il/ MultiProt/) [74]. The alignment of 234 residues achieved an RMSD of $0.66 \AA$

\section{References}

1. Abidi M, Mir AR, Khan F, Ali A, Uddin M (2020) Glycoxidation of LDL generates cytotoxic adducts and elicits humoral response in type 2 diabetes mellitus. Glycobiology. https://doi.org/10.1093/ glycob/cwaa077

2. Acharya P, Luongo TS, Georgiev IS, Matz J, Schmidt SD, Louder MK, Kessler P, Yang Y, McKee K, O'Dell S, Chen L, Baty D, Chames P, Martin L, Mascola JR, Kwong PD (2013) Heavy chainonly IgG2b llama antibody effects near-pan HIV-1 neutralization by recognizing a CD4-induced epitope that includes elements of coreceptor- and CD4-binding sites. J Virol 87:10173-10181

3. Acharya P, Luongo TS, Louder MK, McKee K, Yang Y, Kwon YD, Mascola JR, Kessler P, Martin L, Kwong PD (2013) 
Structural basis for highly effective HIV-1 neutralization by CD4-mimetic miniproteins revealed by 1.5 A cocrystal structure of gp120 and M48U1. Structure 21:1018-1029

4. Akhter F, Salman Khan M, Faisal M, Alatar AA, Ahmad S (2017) Detection of circulating auto-antibodies against ribosylated-LDL in diabetes patients. J Clin Lab Anal 31:e22039

5. Azoitei ML, Correia BE, Ban YE, Carrico C, Kalyuzhniy O, Chen L, Schroeter A, Huang PS, McLellan JS, Kwong PD, Baker D, Strong RK, Schief WR (2011) Computation-guided backbone grafting of a discontinuous motif onto a protein scaffold. Science 334:373-376

6. Azoitei ML, Ban YE, Julien JP, Bryson S, Schroeter A, Kalyuzhniy O, Porter JR, Adachi Y, Baker D, Pai EF, Schief WR (2012) Computational design of high-affinity epitope scaffolds by backbone grafting of a linear epitope. J Mol Biol 415:175-192

7. Bailey JR, Barnes E, Cox AL (2019) Approaches, progress, and challenges to hepatitis $\mathrm{C}$ vaccine development. Gastroenterology 156:418-430

8. Barbas CF 3rd, Collet TA, Amberg W, Roben P, Binley JM, Hoekstra D, Cababa D, Jones TM, Williamson RA, Pilkington GR et al (1993) Molecular profile of an antibody response to HIV-1 as probed by combinatorial libraries. J Mol Biol 230:812-823

9. Behrens AJ, Crispin M (2017) Structural principles controlling HIV envelope glycosylation. Curr Opin Struct Biol 44:125-133

10. Belshe RB, Leone PA, Bernstein DI, Wald A, Levin MJ, Stapleton JT, Gorfinkel I, Morrow RL, Ewell MG, Stokes-Riner A, Dubin G, Heineman TC, Schulte JM, Deal CD, Herpevac Trial for W (2012) Efficacy results of a trial of a herpes simplex vaccine. $\mathrm{N}$ Engl J Med 366:34-43

11. Bos R, van Leuven CJ, Stolk J, Hiemstra PS, Dijkman JH, Nieuwenhuizen W (1995) A monoclonal antibody with high affinity for a neo-antigenic site in fibrinogen degraded by polymorphonuclear leukocyte-derived elastase. Blood Coagul Fibrinolysis 6:259-267

12. Burton DR (2002) Antibodies, viruses and vaccines. Nat Rev Immunol 2:706-713

13. Burton DR (2010) Scaffolding to build a rational vaccine design strategy. Proc Natl Acad Sci USA 107:17859-17860

14. Chen L, Kwon YD, Zhou T, Wu X, O’Dell S, Cavacini L, Hessell AJ, Pancera M, Tang M, Xu L, Yang ZY, Zhang MY, Arthos J, Burton DR, Dimitrov DS, Nabel GJ, Posner MR, Sodroski J, Wyatt R, Mascola JR, Kwong PD (2009) Structural basis of immune evasion at the site of CD4 attachment on HIV-1 gp120. Science 326:1123-1127

15. Deiss TC, Vadnais M, Wang F, Chen PL, Torkamani A, Mwangi W, Lefranc MP, Criscitiello MF, Smider VV (2019) Immunogenetic factors driving formation of ultralong VH CDR3 in Bos taurus antibodies. Cell Mol Immunol 16:53-64

16. Dosztanyi Z, Csizmok V, Tompa P, Simon I (2005) The pairwise energy content estimated from amino acid composition discriminates between folded and intrinsically unstructured proteins. J Mol Biol 347:827-839

17. Dosztanyi Z, Csizmok V, Tompa P, Simon I (2005) IUPred: web server for the prediction of intrinsically unstructured regions of proteins based on estimated energy content. Bioinformatics 21:3433-3434

18. Drews J (2004) Paul Ehrlich: magister mundi. Nat Rev Drug Discov 3:797-801

19. Du J, Wang X, Ma J, Wang J, Qin Y, Zhu C, Liu F, Shao Y, Zhou J, Qiao W, Liu X (2014) Structural and biochemical insights into the V/I505T mutation found in the EIAV gp45 vaccine strain. Retrovirology 11:26

20. Edmundson AB, Ely KR, Herron JN, Cheson BD (1987) The binding of opioid peptides to the Mcg light chain dimer: flexible keys and adjustable locks. Mol Immunol 24:915-935
21. Ehrlich P (1901) Die Seitenkettentheorie und ihre Gegner. Muenchener Med Wochenschr 52:2123-2124

22. Esparza J (2013) A brief history of the global effort to develop a preventive HIV vaccine. Vaccine 31:3502-3518

23. Fischer E (1894) Einfluss der Konfiguration auf die Wirkung der Enzyme. Ber Dt Chem Ges 27:2985-2993

24. Goh GK, Dunker AK, Uversky VN (2008) Protein intrinsic disorder toolbox for comparative analysis of viral proteins. BMC Genom 9(Suppl 2):S4

25. Goh GK, Dunker AK, Uversky VN (2008) A comparative analysis of viral matrix proteins using disorder predictors. Virol J 5:126

26. Goh GK, Dunker AK, Uversky VN (2015) Shell disorder, immune evasion and transmission behaviors among human and animal retroviruses. Mol Biosyst 11:2312-2323

27. Goh GK, Dunker AK, Foster JA, Uversky VN (2019) HIV vaccine mystery and viral shell disorder. Biomolecules 9:178

28. Goh GKM (2017) Viral shapeshifters: strange behavoirs of HIV and other viruses, 1st edn. Simplicity Research Institute, Singapore

29. Goldsby R, Kindt TJ, Osborne BA, Kuby J (2003) Antigens. In: Goldsby R, Osborne BA, Kuby J, Kindt TJ, Marcus DA, Punt J (eds) Immunology. W. H. Freeman and Company, New York, pp $57-75$

30. Griffiths HR (2008) Is the generation of neo-antigenic determinants by free radicals central to the development of autoimmune rheumatoid disease? Autoimmun Rev 7:544-549

31. Huang CC, Venturi M, Majeed S, Moore MJ, Phogat S, Zhang MY, Dimitrov DS, Hendrickson WA, Robinson J, Sodroski J, Wyatt R, Choe H, Farzan M, Kwong PD (2004) Structural basis of tyrosine sulfation and VH-gene usage in antibodies that recognize the HIV type 1 coreceptor-binding site on gp120. Proc Natl Acad Sci USA 101:2706-2711

32. Huang CC, Stricher F, Martin L, Decker JM, Majeed S, Barthe P, Hendrickson WA, Robinson J, Roumestand C, Sodroski J, Wyatt R, Shaw GM, Vita C, Kwong PD (2005) Scorpion-toxin mimics of CD4 in complex with human immunodeficiency virus gp120 crystal structures, molecular mimicry, and neutralization breadth. Structure 13:755-768

33. Kasten FH (1996) Paul Ehrlich: pathfinder in cell biology. 1. Chronicle of his life and accomplishments in immunology, cancer research, and chemotherapy. Biotech Histochem 71:2-37

34. Khattar SK, Samal S, LaBranche CC, Montefiori DC, Collins PL, Samal SK (2013) Comparative immunogenicity of HIV-1 gp160, gp140 and gp120 expressed by live attenuated Newcastle disease virus vector. PLoS ONE 8:e78521

35. Kong L, Lee JH, Doores KJ, Murin CD, Julien JP, McBride R, Liu Y, Marozsan A, Cupo A, Klasse PJ, Hoffenberg S, Caulfield M, King CR, Hua Y, Le KM, Khayat R, Deller MC, Clayton T, Tien H, Feizi T, Sanders RW, Paulson JC, Moore JP, Stanfield RL, Burton DR, Ward AB, Wilson IA (2013) Supersite of immune vulnerability on the glycosylated face of HIV-1 envelope glycoprotein gp120. Nat Struct Mol Biol 20:796-803

36. Kong L, Wilson IA, Kwong PD (2015) Crystal structure of a fully glycosylated HIV-1 gp120 core reveals a stabilizing role for the glycan at Asn262. Proteins 83:590-596

37. Koshland DE Jr (1958) Application of a theory of enzyme specificity to protein synthesis. Proc Natl Acad Sci USA 44:98-104

38. Krammer F, Palese P (2013) Influenza virus hemagglutinin stalk-based antibodies and vaccines. Curr Opin Virol 3:521-530

39. Krarup A, Truan D, Furmanova-Hollenstein P, Bogaert L, Bouchier P, Bisschop IJM, Widjojoatmodjo MN, Zahn R, Schuitemaker H, McLellan JS, Langedijk JPM (2015) A highly stable prefusion RSV F vaccine derived from structural analysis of the fusion mechanism. Nat Commun 6:8143 
40. Kulkarni P, Uversky VN (2018) Intrinsically disordered proteins: the dark horse of the dark proteome. Proteomics 18:e1800061

41. Kunert R, Ruker F, Katinger H (1998) Molecular characterization of five neutralizing anti-HIV type 1 antibodies: identification of nonconventional D segments in the human monoclonal antibodies 2G12 and 2F5. AIDS Res Hum Retroviruses 14:1115-1128

42. Kwon YD, Finzi A, Wu X, Dogo-Isonagie C, Lee LK, Moore LR, Schmidt SD, Stuckey J, Yang Y, Zhou T, Zhu J, Vicic DA, Debnath AK, Shapiro L, Bewley CA, Mascola JR, Sodroski JG, Kwong PD (2012) Unliganded HIV-1 gp120 core structures assume the CD4-bound conformation with regulation by quaternary interactions and variable loops. Proc Natl Acad Sci USA 109:5663-5668

43. Kwon YD, LaLonde JM, Yang Y, Elban MA, Sugawara A, Courter JR, Jones DM, Smith AB 3rd, Debnath AK, Kwong PD (2014) Crystal structures of HIV-1 gp120 envelope glycoprotein in complex with NBD analogues that target the CD4-binding site. PLoS ONE 9:e85940

44. Kwong PD, Wyatt R, Majeed S, Robinson J, Sweet RW, Sodroski J, Hendrickson WA (2000) Structures of HIV-1 gp120 envelope glycoproteins from laboratory-adapted and primary isolates. Structure 8:1329-1339

45. Kwong PD, Mascola JR, Nabel GJ (2013) Broadly neutralizing antibodies and the search for an HIV-1 vaccine: the end of the beginning. Nat Rev Immunol 13:693-701

46. Lapage G (1952) Paul Ehrlich. Nature 169:362

47. Lee JH, Andrabi R, Su CY, Yasmeen A, Julien JP, Kong L, Wu NC, McBride R, Sok D, Pauthner M, Cottrell CA, Nieusma T, Blattner C, Paulson JC, Klasse PJ, Wilson IA, Burton DR, Ward AB (2017) A broadly neutralizing antibody targets the dynamic HIV envelope trimer apex via a long, rigidified, and anionic betahairpin structure. Immunity 46:690-702

48. Lemieux RU, Spohr U (1994) How Emil Fischer was led to the lock and key concept for enzyme specificity. Adv Carbohydr Chem Biochem 50:1-20

49. Leonard CK, Spellman MW, Riddle L, Harris RJ, Thomas JN, Gregory TJ (1990) Assignment of intrachain disulfide bonds and characterization of potential glycosylation sites of the type 1 recombinant human immunodeficiency virus envelope glycoprotein (gp120) expressed in Chinese hamster ovary cells. J Biol Chem 265:10373-10382

50. Leroux C, Cadore JL, Montelaro RC (2004) Equine infectious anemia virus (EIAV): what has HIV's country cousin got to tell us? Vet Res 35:485-512

51. Li F, Craigo JK, Howe L, Steckbeck JD, Cook S, Issel C, Montelaro RC (2003) A live attenuated equine infectious anemia virus proviral vaccine with a modified $\mathrm{S} 2$ gene provides protection from detectable infection by intravenous virulent virus challenge of experimentally inoculated horses. J Virol 77:7244-7253

52. Masignani V, Rappuoli R, Pizza M (2002) Reverse vaccinology: a genome-based approach for vaccine development. Expert Opin Biol Ther 2:895-905

53. McLellan JS, Pancera M, Carrico C, Gorman J, Julien JP, Khayat R, Louder R, Pejchal R, Sastry M, Dai K, O’Dell S, Patel N, Shahzad-ul-Hussan S, Yang Y, Zhang B, Zhou T, Zhu J, Boyington JC, Chuang GY, Diwanji D, Georgiev I, Kwon YD, Lee D, Louder MK, Moquin S, Schmidt SD, Yang ZY, Bonsignori M, Crump JA, Kapiga SH, Sam NE, Haynes BF, Burton DR, Koff WC, Walker LM, Phogat S, Wyatt R, Orwenyo J, Wang LX, Arthos J, Bewley CA, Mascola JR, Nabel GJ, Schief WR, Ward AB, Wilson IA, Kwong PD (2011) Structure of HIV-1 gp120 V1/V2 domain with broadly neutralizing antibody PG9. Nature 480:336-343
54. Meszaros B, Erdos G, Dosztanyi Z (2018) IUPred2A: contextdependent prediction of protein disorder as a function of redox state and protein binding. Nucleic Acids Res 46:W329-W337

55. Montelaro RC, Grund C, Raabe M, Woodson B, Cook RF, Cook S, Issel CJ (1996) Characterization of protective and enhancing immune responses to equine infectious anemia virus resulting from experimental vaccines. AIDS Res Hum Retroviruses 12:413-415

56. Neurath AR, Rubin BA (1971) Viral structural components as immunogens of prophylactic value. Karger, Basel

57. Ofek G, Tang M, Sambor A, Katinger H, Mascola JR, Wyatt R, Kwong PD (2004) Structure and mechanistic analysis of the antihuman immunodeficiency virus type 1 antibody 2 F5 in complex with its gp41 epitope. J Virol 78:10724-10737

58. Osterholm MT, Kelley NS, Sommer A, Belongia EA (2012) Efficacy and effectiveness of influenza vaccines: a systematic review and meta-analysis. Lancet Infect Dis 12:36-44

59. Pallesen J, Wang N, Corbett KS, Wrapp D, Kirchdoerfer RN, Turner HL, Cottrell CA, Becker MM, Wang L, Shi W, Kong WP, Andres EL, Kettenbach AN, Denison MR, Chappell JD, Graham BS, Ward AB, McLellan JS (2017) Immunogenicity and structures of a rationally designed prefusion MERS-CoV spike antigen. Proc Natl Acad Sci USA 114:E7348-E7357

60. Peng K, Vucetic S, Radivojac P, Brown CJ, Dunker AK, Obradovic Z (2005) Optimizing long intrinsic disorder predictors with protein evolutionary information. J Bioinform Comput Biol 3:35-60

61. Peng K, Radivojac P, Vucetic S, Dunker AK, Obradovic Z (2006) Length-dependent prediction of protein intrinsic disorder. BMC Bioinform 7:208

62. Purtscher M, Trkola A, Gruber G, Buchacher A, Predl R, Steindl F, Tauer C, Berger R, Barrett N, Jungbauer A et al (1994) A broadly neutralizing human monoclonal antibody against gp41 of human immunodeficiency virus type 1. AIDS Res Hum Retroviruses 10:1651-1658

63. Rappuoli R (2001) Reverse vaccinology, a genome-based approach to vaccine development. Vaccine 19:2688-2691

64. Regep C, Georges G, Shi J, Popovic B, Deane CM (2017) The H3 loop of antibodies shows unique structural characteristics. Proteins 85:1311-1318

65. Rinaudo CD, Telford JL, Rappuoli R, Seib KL (2009) Vaccinology in the genome era. J Clin Invest 119:2515-2525

66. Robinson LN, Tharakaraman K, Rowley KJ, Costa VV, Chan KR, Wong YH, Ong LC, Tan HC, Koch T, Cain D, Kirloskar R, Viswanathan K, Liew CW, Tissire H, Ramakrishnan B, Myette JR, Babcock GJ, Sasisekharan V, Alonso S, Chen J, Lescar J, Shriver Z, Ooi EE, Sasisekharan R (2015) Structure-guided design of an antidengue antibody directed to a non-immunodominant epitope. Cell 162:493-504

67. Romero P, Obradovic Z, Li X, Garner EC, Brown CJ, Dunker AK (2001) Sequence complexity of disordered protein. Proteins 42:38-48

68. Saini SS, Allore B, Jacobs RM, Kaushik A (1999) Exceptionally long $\mathrm{CDR} 3 \mathrm{H}$ region with multiple cysteine residues in functional bovine IgM antibodies. Eur J Immunol 29:2420-2426

69. Samberg NL, Bray RA, Gewurz H, Landay AL, Potempa LA (1988) Preferential expression of neo-CRP epitopes on the surface of human peripheral blood lymphocytes. Cell Immunol 116:86-98

70. Sanna PP, Williamson RA, De Logu A, Bloom FE, Burton DR (1995) Directed selection of recombinant human monoclonal antibodies to herpes simplex virus glycoproteins from phage display libraries. Proc Natl Acad Sci USA 92:6439-6443

71. Saphire EO, Parren PW, Pantophlet R, Zwick MB, Morris GM, Rudd PM, Dwek RA, Stanfield RL, Burton DR, Wilson IA (2001) 
Crystal structure of a neutralizing human IGG against HIV-1: a template for vaccine design. Science 293:1155-1159

72. Schiller J, Chackerian B (2014) Why HIV virions have low numbers of envelope spikes: implications for vaccine development. PLoS Pathog 10:e1004254

73. Shahab U, Ahmad S, Moinuddin DK, Habib S, Alam K, Ali A (2012) Hydroxyl radical modification of collagen type II increases its arthritogenicity and immunogenicity. PLoS ONE 7:e31199

74. Shatsky M, Nussinov R, Wolfson HJ (2004) A method for simultaneous alignment of multiple protein structures. Proteins 56:143-156

75. Sheets RL, Zhou T, Knezevic I (2016) Review of efficacy trials of HIV-1/AIDS vaccines and regulatory lessons learned: a review from a regulatory perspective. Biologicals 44:73-89

76. Shriver Z, Trevejo JM, Sasisekharan R (2015) Antibody-based strategies to prevent and treat influenza. Front Immunol 6:315

77. Smith TJ, Chase ES, Schmidt TJ, Olson NH, Baker TS (1996) Neutralizing antibody to human rhinovirus 14 penetrates the receptorbinding canyon. Nature 383:350-354

78. Sok D, van Gils MJ, Pauthner M, Julien JP, Saye-Francisco KL, Hsueh J, Briney B, Lee JH, Le KM, Lee PS, Hua Y, Seaman MS, Moore JP, Ward AB, Wilson IA, Sanders RW, Burton DR (2014) Recombinant HIV envelope trimer selects for quaternary-dependent antibodies targeting the trimer apex. Proc Natl Acad Sci USA 111:17624-17629

79. Sok D, Le KM, Vadnais M, Saye-Francisco KL, Jardine JG, Torres JL, Berndsen ZT, Kong L, Stanfield R, Ruiz J, Ramos A, Liang CH, Chen PL, Criscitiello MF, Mwangi W, Wilson IA, Ward AB, Smider VV, Burton DR (2017) Rapid elicitation of broadly neutralizing antibodies to HIV by immunization in cows. Nature 548:108-111

80. Stanfield RL, Wilson IA, Smider VV (2016) Conservation and diversity in the ultralong third heavy-chain complementarity-determining region of bovine antibodies. Sci Immunol 1:aaf7962. https ://doi.org/10.1126/sciimmunol.aaf7962

81. Stanfield RL, Berndsen ZT, Huang R, Sok D, Warner G, Torres JL, Burton DR, Ward AB, Wilson IA, Smider VV (2020) Structural basis of broad HIV neutralization by a vaccine-induced cow antibody. Sci Adv 6:eaba0468

82. Tagmyer TL, Craigo JK, Cook SJ, Even DL, Issel CJ, Montelaro RC (2008) Envelope determinants of equine infectious anemia virus vaccine protection and the effects of sequence variation on immune recognition. J Virol 82:4052-4063

83. Van Leuven F, Cassiman JJ, Van den Berghe H (1986) Human pregnancy zone protein and alpha 2-macroglobulin. High-affinity binding of complexes to the same receptor on fibroblasts and characterization by monoclonal antibodies. J Biol Chem 261:16622-16625

84. Van Leuven F, Marynen P, Cassiman JJ, Van den Berghe H (1986) The epitopes of two complex-specific monoclonal antibodies, related to the receptor recognition site, map to the $\mathrm{COOH}$-terminal end of human alpha 2-macroglobulin. J Biol Chem 261:6933-6937

85. Van Regenmortel MH (1966) Plant virus serology. Adv Virus Res 12:207-271

86. Van Regenmortel MH (1992) The conformational specificity of viral epitopes. FEMS Microbiol Lett 100:483-487

87. Vigerust DJ, Shepherd VL (2007) Virus glycosylation: role in virulence and immune interactions. Trends Microbiol 15:211-218
88. Wang F, Ekiert DC, Ahmad I, Yu W, Zhang Y, Bazirgan O, Torkamani A, Raudsepp T, Mwangi W, Criscitiello MF, Wilson IA, Schultz PG, Smider VV (2013) Reshaping antibody diversity. Cell 153:1379-1393

89. Wang HN, Rao D, Fu XQ, Hu MM, Dong JG (2018) Equine infectious anemia virus in China. Oncotarget 9:1356-1364

90. Wang XF, Lin YZ, Li Q, Liu Q, Zhao WW, Du C, Chen J, Wang X, Zhou JH (2016) Genetic Evolution during the development of an attenuated EIAV vaccine. Retrovirology 13:9

91. Ward B (2007) Antiviral vaccines. In: Acheson NH (ed) Fundamentals of molecular virology. Wiley, Hoboken, pp 428-455

92. West AP Jr, Galimidi RP, Foglesong CP, Gnanapragasam PN, Huey-Tubman KE, Klein JS, Suzuki MD, Tiangco NE, Vielmetter J, Bjorkman PJ (2009) Design and expression of a dimeric form of human immunodeficiency virus type 1 antibody 2 G12 with increased neutralization potency. J Virol 83:98-104

93. Xue B, Dunbrack RL, Williams RW, Dunker AK, Uversky VN (2010) PONDR-FIT: a meta-predictor of intrinsically disordered amino acids. Biochem Biophys Acta 1804:996-1010

94. Yamada H, Tamada T, Kosaka M, Miyata K, Fujiki S, Tano M, Moriya M, Yamanishi M, Honjo E, Tada H, Ino T, Yamaguchi H, Futami J, Seno M, Nomoto T, Hirata T, Yoshimura M, Kuroki R (2007) "Crystal lattice engineering", an approach to engineer protein crystal contacts by creating intermolecular symmetry: crystallization and structure determination of a mutant human RNase 1 with a hydrophobic interface of leucines. Protein Sci 16:1389-1397

95. Zhou T, Xu L, Dey B, Hessell AJ, Van Ryk D, Xiang SH, Yang $\mathrm{X}$, Zhang MY, Zwick MB, Arthos J, Burton DR, Dimitrov DS, Sodroski J, Wyatt R, Nabel GJ, Kwong PD (2007) Structural definition of a conserved neutralization epitope on HIV-1 gp120. Nature 445:732-737

96. Zhou T, Lynch RM, Chen L, Acharya P, Wu X, Doria-Rose NA, Joyce MG, Lingwood D, Soto C, Bailer RT, Ernandes MJ, Kong R, Longo NS, Louder MK, McKee K, O’Dell S, Schmidt SD, Tran L, Yang Z, Druz A, Luongo TS, Moquin S, Srivatsan S, Yang Y, Zhang B, Zheng A, Pancera M, Kirys T, Georgiev IS, Gindin T, Peng HP, Yang AS, Program NCS, Mullikin JC, Gray MD, Stamatatos L, Burton DR, Koff WC, Cohen MS, Haynes BF, Casazza JP, Connors M, Corti D, Lanzavecchia A, Sattentau QJ, Weiss RA, West AP Jr, Bjorkman PJ, Scheid JF, Nussenzweig MC, Shapiro L, Mascola JR, Kwong PD (2015) Structural repertoire of HIV1-neutralizing antibodies targeting the CD4 supersite in 14 donors. Cell 161:1280-1292

97. Zhou T, Xu K (2018) Structural features of broadly neutralizing antibodies and rational design of vaccine. Adv Exp Med Biol 1075:73-95

Publisher's Note Springer Nature remains neutral with regard to jurisdictional claims in published maps and institutional affiliations. 